\title{
Resistive Traits of the Tunisian Medina Bazaars' Architectural Spaces in the Globalized World
}

\author{
Tunus Medina Çarşılarının Mimari Mekanlarının \\ Resistatif Özellikleri Üzerine Bir İrdeleme
}

\author{
Yasmine TíRA, Çiğdem CANBAY TÜRKYILMAZ
}

\section{ABSTRACT}

In ancient times, bazaars were an integral part of the city life; bifurcating from the city structure and reflecting each period of time's architectural characteristics. It is also said that they are the source of 20 communications and trade activities. However, due to the quick changes in the cities' spatial configurations that we are living in, these traditional spaces started to run a risk of possible cultural continuity alteration. But, despite the disturbing contradiction which is affecting their traditional allure, they still reflect an undying identity. They are still talking about the engraved cultural memory thro ugh several architectural traits and spatial experiences. This paper aims to highlight the significance of the 25 Medina of Tunis bazaars' resistance against globalization. The present study case analysis lead to a conceptual framing of cultural continuity's model being a tripartite relation between identity, heritage and collective memory. Through this research, it had been concluded that several resistance traits witness that the Medina of Tunis is still showing a cultural continuity able to counter the market capitalization.

Keywords: Cultural continuity,; globalization; identity; traditional bazaars.

ÖZ

Geleneksel kentlerin ayrılmaz bir parçası olan çarşılar, kent yapılaşmasının çeşitli zaman dilimlerindeki mimari özelliklerini yansıtan, aynı zamanda ticaret aktivitelerinin yanısıra kent içi iletişimin gerçekleştiği mekanlar bütünüdür. Çeşitli mekansal deneyimler aracılığıyla kent belleğinin kazındığı geleneksel çarşıların kültürel süreklilikleri, günümüzde kentlerin hızlı mekansal değişimleri karşısında tehdit altındadır. Bu çalışma, Dünya Kültür Mirası olan Tunus Medina çarşılarının küreselleşme karşısındaki direnişlerinin önemini ortaya koymayı amaçlamaktadır. Kimlik, miras ve kolektif belleğin üçlü ilişkisinden ortaya çıkan kavramsal bir kültürel süreklilik modeli ortaya konmuş ve bu modeli desteklemek üzere bir alan çalışması gerçekleştirilmiştir. Sonuçta, Tunus Medina geleneksel çarşıları, kapitalist ticaret karşısında, kültürel sürekliliğini korumasına yardımcı olan çeşitli resistatif özelliklerini halen devam ettirebilmektedir.

Anahtar sözcükler: Kültürel süreklilik; küreselleşme; kimlik; geleneksel çarşılar.

Department of Architecture, Yıldız Technical University Faculty of Architecture, İstanbul, Turkey

Article arrival date: January 30, 2017 - Accepted for publication: May 22, 2017

Correspondence: Yasmine TiRA. e-mail: yasminetira@gmail.com

○ 2017 Yıldız Teknik Üniversitesi Mimarlık Fakültesi - 02017 Yıldız Technical University, Faculty of Architecture 


\section{Introduction}

In the current interconnected unified world it became legitimized to wonder about traditional spaces' identity in general and covered bazaars' resistance against the globalized quick changes with a specific way. As described by the Iranian award winning international architect Nader Ardalan, 'public gardens, pathways, streets and covered streets such as bazaars and souks, with their urban contexts are all considered as "places of public gathering". Those ones are an included part from the concentric planning concept bifurcating from the Friday Mosque and the place of government in Middle Eastern and North African Islamic cities. And as by the French anthropologist Marc Augé, places of everyday gathering, which he described as circulation, consumption and communication spaces are empirical non-spaces. They are spaces showing the existence of social relations. These ones define what is called 'globalization'. According to Marc Augé, ideology of the world's globalization supposes the borders and dissents eliminated. However, this implies that traditional covered bazaars' identity is in risk as he explained that consumption and communication spaces' urbanization in general, is supposed to be the expression of this systemic relation.

This research, addresses issues of the interaction between modern and traditional; it is common to see the inclusion of small shops reflecting the pure modernity in the middle of traditional environments. In fact, the anchor point in traditional bazaars' evolution over time is the ability to keep reflecting their identity and cultural continuity.

What seems appealing in the relation between identity, architectural heritage and cultural continuity is that shaping of architectural identity is to some extent dependent on heritage:

"The questioning of the role of tradition and heritage in the shaping of architectural identity has become a necessity" (Ashraf Salama 2012, p179).

As by German Egyptologist Jan Assman, the synthesis of time and identity is the gage of memory. This memory is itself either individual or social and it is what enhances the social experience of the space. The present paper highlights the role of architectural identity's evolving over time on the experience's definition of traditional bazaars (Figure 1).

The present research's main purpose is to witness the Beylik Area Bazaar's current resistive state against globilization trends; it is still unkown whether this historical site will remain and resist again in the coming years or it will distinguish slowly. Thus it is hypothesized that the resistive features of traditional bazaars are dependent on cultural continuity. This continuity itself is not only related to the trading area's spatial configuration or functional organization but it is also related to an engraved collective memory which in return is related to two other key concepts i.e. Identity and heritage. All of these interconnected factors when combined, form the cultural continuity. The supposed relation presented in Figure 2 reinforces an observation made during field visit regarding cultural continuity i.e. resistance against globalization trends in the Medina of Tunis.

The main method of the study is an analysis of a small part from the Tunisian Medina's bazaars in terms of its functional organization, spatial configuration and urban context's evolution. For this aim, a site reading has been conducted. The selected 'bazaars' analysis have a specific focus on the cultural continuity and the 'collective memory' reflection through the different experiences they provide for users. In this respect, the prevalent resistance of the traditional Medina in the globalized world is discussed.

\section{Medina of Tunis: From a City Center to Memorial Traditional Bazaars}

The formal configuration of the Tunisian Medina has undergone relatively few transformations since ancient times but it still reflects a remarkable typo-morphological continuity spanning several centuries. From the 7th century till

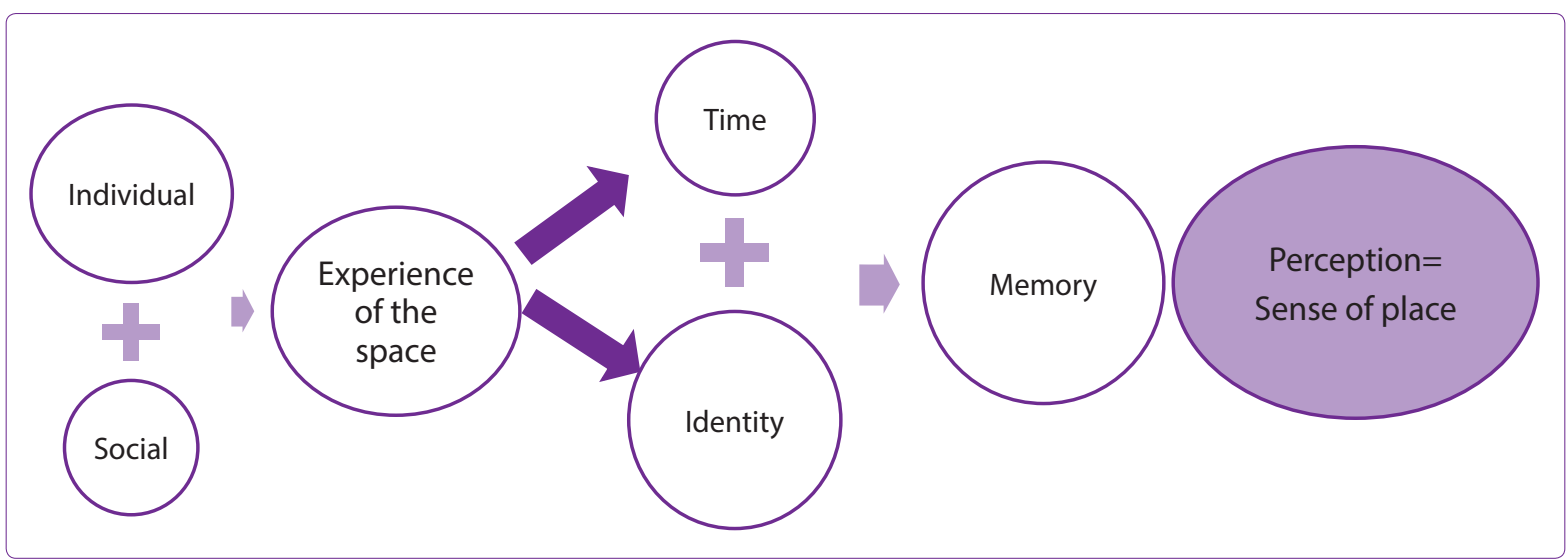

Figure 1. Sense of place/identity relation (provided by authors). 


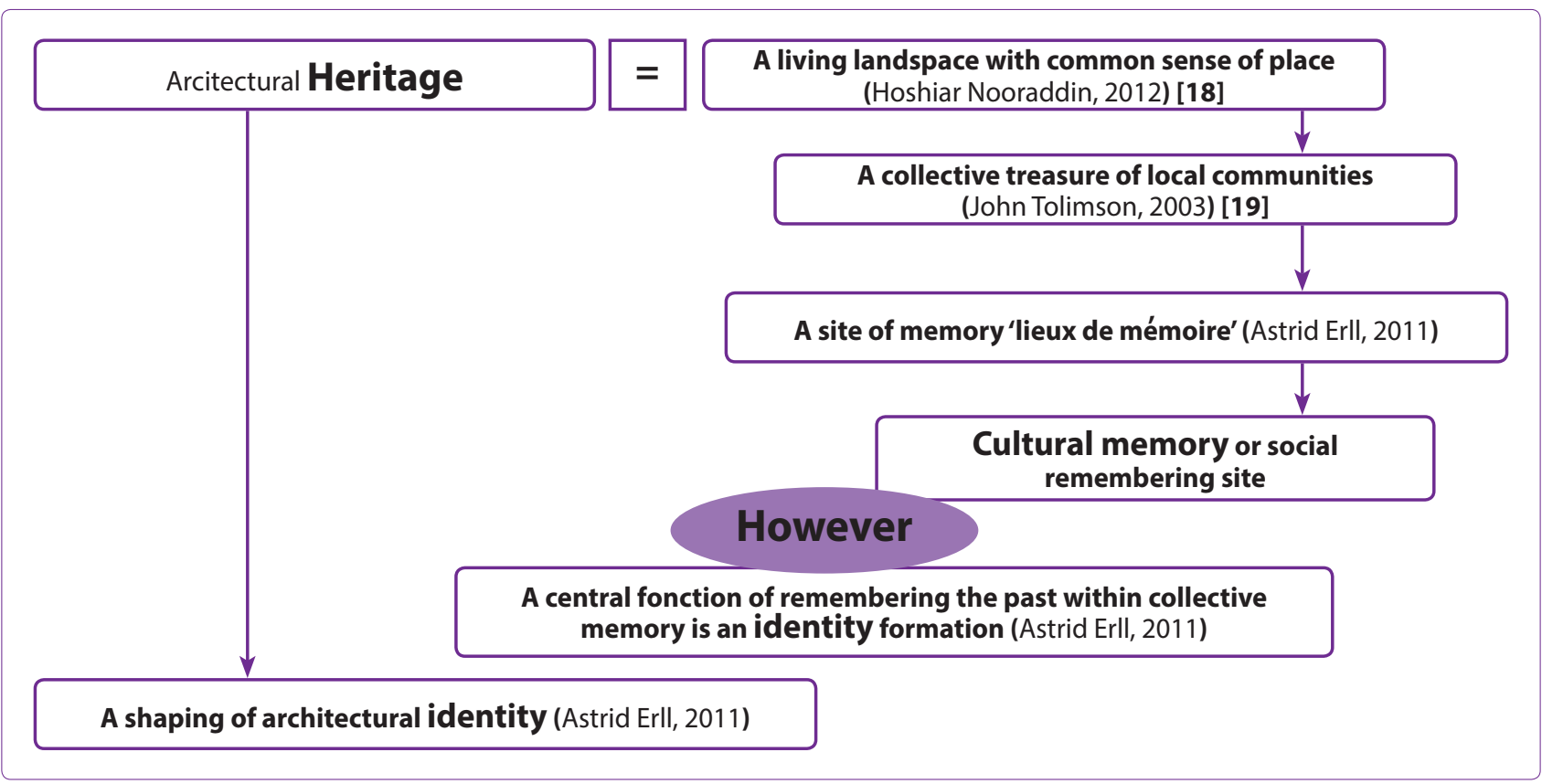

Figure 2. The tripartite relation heritage, identity, cultural memory's conceptual framing (provided by authors).

nowadays, the Medina had lived different mutations especially in its core: the collection of souks.

From $8^{\text {th }}$ Till $16^{\text {th }}$ Century: The Structure of the Arabic City

The history of the Medina dates from the establishment of 'Al-Zaytouna' Mosque in year 695 by the first coming Arabs who could force out the last Byzantines. However, it was proved after some archeological excavations that the city existed even before Arabs' conquest. It was even mentioned that the city had a neutral urban structure, a city with destroyed city walls, ready to be rebuilt.

Starting from 711 until 909 under the Aghlabids, the Medina of Tunis underwent different evolutions like the reconstruction of the city walls and the redefinition of the center and principle souks around 'Al-Zaytouna' mosque. It can be said that there was a double construction attempt which had greatly defined the city structure; marking the city's limits with walls and giving a specific religious center which is the said 'Al-Zaytouna' mosque. According to those two main structures, bazaars or souk started to appear following a logically defined tracing of the city structure.

However, after 949 a Saint man named Sidi Mehrez, built again the Medina's walls and souks joining to them the Jewish district, 'El Hara'. Supported by its geographical location, the Medina was the meeting point of traders coming from the different surrounding costal countries like Normans of Cecilia (Figure 3).

Around 1147, the Medina's structure changed again under Almohads regency who started to construct new buildings reflecting their own identity. The most important and remaining till nowadays is the 'Kasbah' which was defined as the center of military and political power. After 1228 the Hafsids regency started and lasted three and a half century. It reflected a great development of the urban fabric, the economic and social sectors. And it is with this regency that luxury products' markets appeared; leather and textile bazaars with a specific way.

\section{Medina of Tunis from the Ottoman Empire Till the} French Protectorate

As by Jallel Abdelkefi starting from the Ottoman Empire until the French protectorate several political facts influenced the urban planning. By September 1574, Ottoman soldiers coming from Istanbul with Sinan Pasha's fleet took control of 'La Goulette', costal part of the capital Tunis. First Beylerbeys of the regency like Haydar, Rajab, Jafar, Mustafâ, Hasan, Mouhammed, Husayn Pasha, had not left any important architectural realization. By the end of the $16^{\text {th }}$ century, the Ottomans started repairing the city walls, renovated 'Al Kasba' which was transformed to 'Diwan'. And as by Ahmed Saadaoui, Pashas' regime finished by 1597 right at the time when the Medina's reconstruction started under 'Uthmân Dey'. After him, started the power of Yüsuf Dey, whith whom Deys' domination attended its apogee.

The end of the Ottoman Empire can be considered as an important phase in the Medina's urban evolution. The status of Ulema started to change under Ottoman ruler Ahmed Bey and it marked a stagnation period in the urban development of central Medina. However, as announced by Abdelkafi, those religious intellectuals had participated unintentionally in the political life since they were concen- 


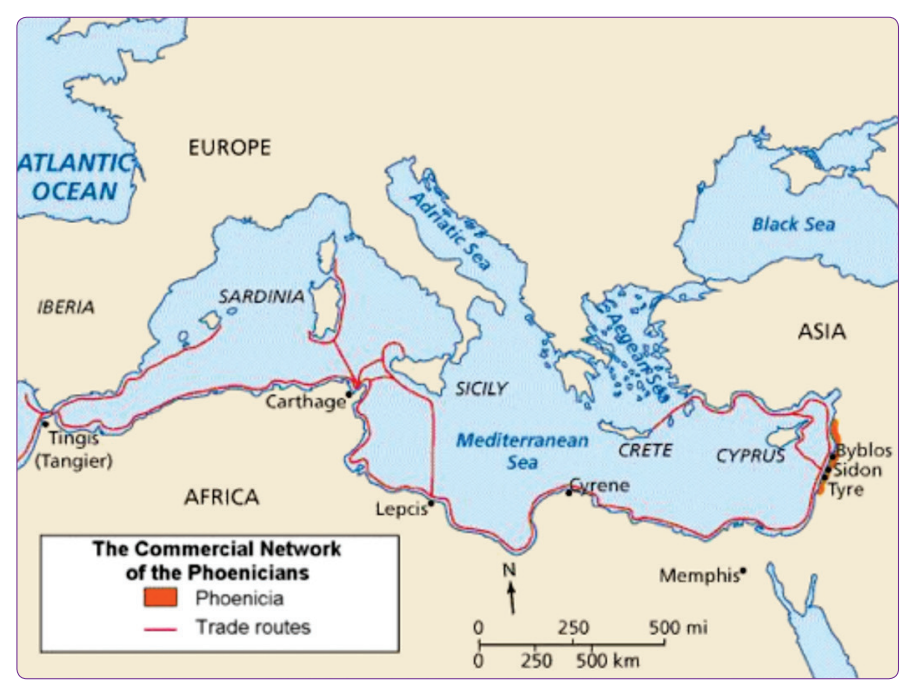

Figure 3. Important trade routes with respect to trade activities of Medina.

trated in the 'Zaytouna' mosque which was the studying, praying and political mobilization area: "People were considering the big Mosque like their Hotel de Ville, they used to meet there protected from the power's supervision. They deliberate and take decisions. The mosque is the city dwellers' forum in the Maghreb cities."

With the French Protectorship of Tunisia by 1881, a second new westernized city, inhabited by Europeans started to evolve right next to the Medina. This new city named "La Ville nouvelle" or "Ville européenne" had a different morphological and functional form from the old Medina. As it was mentioned by Anton Escher and Marianne Schepers, "during the French protectorate, the Medina was viewed by all actors at that time as the antithesis to the Ville nouvelle. This difference is based on morphological opposites." In fact, for the French government, the old Medina was a symbol of Tunisian people's backwardness. Thus, they had identified a proper French way of life in the new city. This attempt made the Tunisians be further attached to their religion, national and cultural identity. In short, it became the symbol of the resistance against colonial attempt.

\section{Site Reading: 'Beylik' Area's Bazaars of the Tunisian Medina}

The 'Beylik' area is located in one third part of the axe passing from "Al-Kasbah" and reaching "Bab-Behar", around "Al-Zaytouna" mosque, where most of the covered streets are concentrated. It has been named 'Beylik' referring to the Turkish meaning of governance. The area's location is considered as a sensitive place since it is joined to the current prime ministry's building, "Dar-Al bey". The two main bazaars of the Beylik Area are Al-Berka and AlTruk bazaars. Due to their cultural significance, they had been chosen for the course of this study.

The Tunisian Medina had seen its spatial configuration changing slowly affecting the bazaars initial state. What enhanced the choice of this site with a specific way is the inherited resistance trait of the Medina. Its whole spatial configuration was done in a spider form having 'Al-Zaytouna' mosque as an anchor point. Streets were intentionally made exaggeratedly narrow to provide a kind of privacy to the area. In old times, none from exterior can easily cross the city walls to get in the souks' heart.

Apart from that, the medina's history is a reflection of the Tunisian's collective memory; as described by Jallel Abdelkafi, it is "the historical space" of Tunisian agglomeration. And it was just after the end of the 19th century that a new city had been established beside the old Medina, a new center of Tunis which was defined as the colonial center.

\section{The Central Medina's Core of 'Souks'}

According to studies conducted by the Association for the safeguarding of the Medina of Tunis, the central Medina currently has an area of 100 hectares. Under the Hafsids regency, the textile industry developed several new practices like silk, wool and cotton weaving, spinning wool, trimming and dyeing. This enhanced the appearance of new bazaars which can be defined in three circles; the first is 'El Attarine, el Chammaine, el Saffarine, el Rbaa, el Kachchachine, el Koutbia, el Qmech, el Sayghiyya', situated in the heart. The second circle comprises of, 'el Najara (which is still existing with the same function), el Haddedin, el Sabbaghin, el Qsaderjiyya', in the peripheral districts of the Medina. And finally, the third circle, 'el Qallalin, el Halfaouin, el Tabbabin, el Jazzarin, Souk el Hout (fish market), is located outside the city walls.

The term 'souk' owes its origin to an Arabic term meaning 'drive' or 'go ahead'. Professions' names had an important influence on the urban nomenclature which proves the importance of craftsmen and tradesmen in the Tunisian social life. According to Arthur Pellegrin, 37 different souks were existing in the 8th century. Their names were referring to the different existing commercial activities.

\section{Immediate Urban Context of the Central Medina}

The access ways to the central Medina are local roads easily accessible for pedestrians. The whole central Medina is connected to the outside by its pedestrian arteries. Therefore, a sense of continuity between the Medina and its immediate urban context is present through pedestrian experience. It can be said that the structure of the bazaars has continuity to the city structure. There is no exterior façade creating a separation between the new capital established in the colonial period and the old city center arranged around the Zaytouna mosque. 


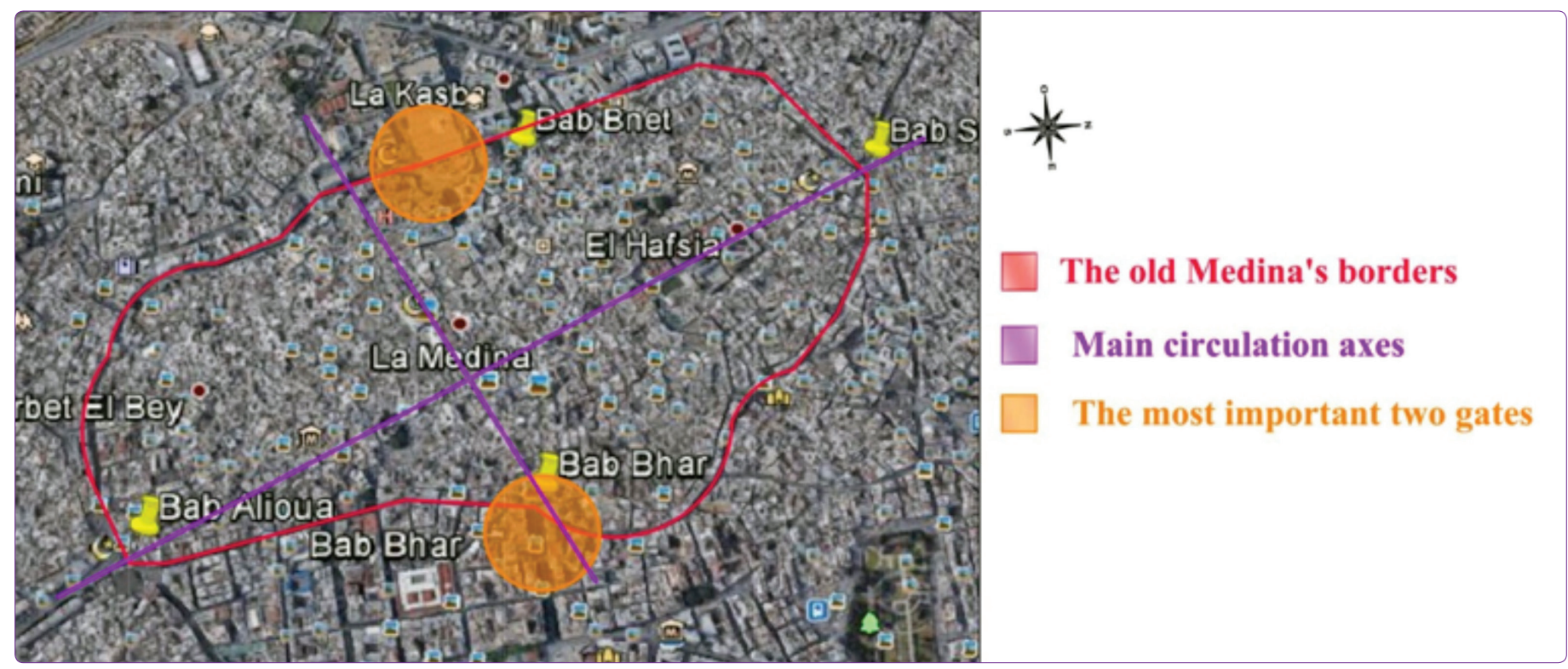

Figure 4. Borders and main gates of the central Medina (Provided by authors after Google earth).

The main connection points between interior and exterior are the central Medina's two main gates, "Bab Behar" from the east and "Al-Kasba" from the west. These main entrances control the passage. However, "Bab-Behar" gate is still remaining in its traditional appearance. Other gates has also been kept, like "Bab-Bnet", "Bab-Alkhadhra", "Bab-Laasall", "Bab-Souika" but only the previous two main gates are an object of interest in this study since the chosen area is located in their axe (Figure 4).

The chosen area is located in the 1/3 part of the axe passing from "Al-Kasbah" and reaching "Bab-Behar", around "Al-Zaytouna" mosque and where most of the covered streets are concentrated. The area's location is considered as a sensitive place since it is joined to the prime ministry's building, "Dar-Al Bey" which has kept its function from the time of its establishment by the first Mouradit Beys in the $16^{\text {th }}$ century. This border is known as "AL-Kasbah" which was established by Almohads from the middle of the $12^{\text {th }}$ century. This regency palace was considered as a separate small city because of its important size; $1 / 14^{\text {th }}$ from the whole Medina's area at that time.

Being under control and safeguarding of the ASM, ${ }^{1}$ the whole surrounding area of 'Al-Zaytouna' mosque had kept some traits from its traditional aspect. Thus it can be noticed that its arteries remained almost same. And as described by Abdelkafi, the traditional urban weaving was in a specific time of the Medina's development not suitable for traffic and was presenting an obstacle for the capital modernization attempts. Thus, many urban renovation attempts had been suggested like breakthroughs, cuttings, aerations and demolitions.

\footnotetext{
1 ASM: Association of safeguarding of the Medina.
}

Some of those suggestions had been useful and contributed to the improvement of the historical urban space. Some suggestions, however, were found to be counterproductive and were hence discarded. As he said "Despite dilapidations, smashing and mutilations, historical space is yet asserting its existence." It is a habitation, work and consumption space which is enough alive to prove the improbability of its disappearing. "A social and economic dynamic is inside, enhancing a new urbanity of the historical space."And as it can be noticed in the Figure 5 , the Medina is still showing a centrality around "Al-Zaytouna" mosque, from which several pedestrian arteries are bifurcating.

\section{Spatial Configuration and Functional Organization of the Beylik Area's Bazaars}

As it can be noticed from the Figure 6, most of the Medina's bazaars are concentrated around "Al-Zaytouna mosque". However, not all of them are covered. This shows the changes in some streets' functions from the time of their establishment till presently.

According to Zoubeir Almoulhi, several parts from the central Medina started to change function since 2000 when a better interest was given to the area's value in the touristic field. Thus, many damaged homes, workshops and depository spaces took another function. A lot of facilities subjected to tourists appeared like cafes. Many old homes became luxurious guest houses or restaurants like "Dar-Eljild" which was the old Ottoman "Dîwân" (Figure 7).

Although the covered streets of the Medina's bazaars existed from the Hafsides times, they flourished the most during the Ottoman Empire. Thus, the chosen site is an 
area which flourished under one of the first Ottoman Deys and Beys.

The Beylik area had been mostly defined under Yüsuf Dey's regency, between 1610 and 1637. In fact, one of the most important changes in the Medina under Yüsuf Dey's power is that he tried to use Andalusians' knowledge in crafts and urbanism. In fact, it was from them that the famous traditional Tunisian wool cap was taken and for which 'Chechiya' souks were established. It dominated the local economy and enhanced exportations to close countries. Besides this new craft, with Andalusians' coming, even silk weaving owed a bazaar. Many of them still exist till nowadays, like Yüsuf Dey's mosque which developed the urban organization of all its surrounding area. Thereby, it is around this monument that till nowadays' existing bazaars were established.

\section{'Al-Truk' Souk}

One of the specified area's bazaar is 'Al-Truk' souk; the Turkish bazaar which is one of the most important covered bazaars of the Medina. It is relatively long and it relates the Zaytouna mosque to Yüsuf Dey's mosque. In the times of its establishment it was $6 \mathrm{~m}$ large, a paved street with a median gutter. It is in this bazaar that tailors can be found in a continuous number of shops, in a street covered with

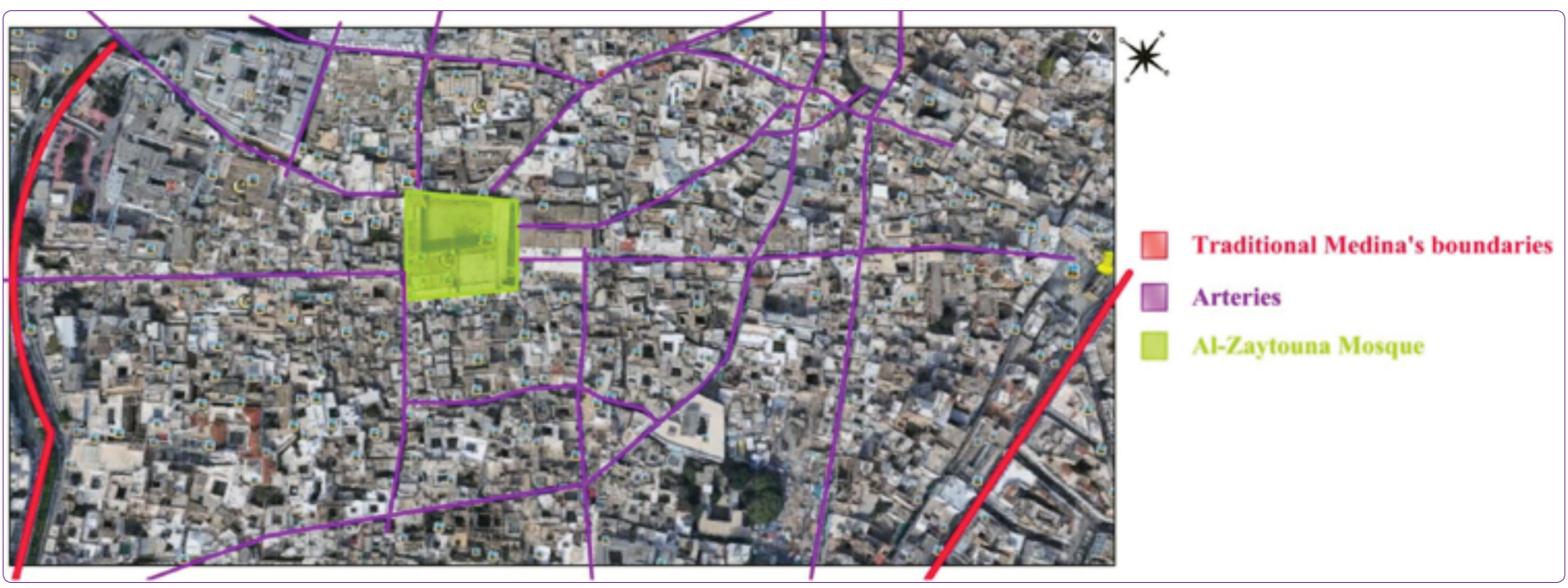

Figure 5. Immediate urban context of the chosen area (Provided by authors after Google earth).

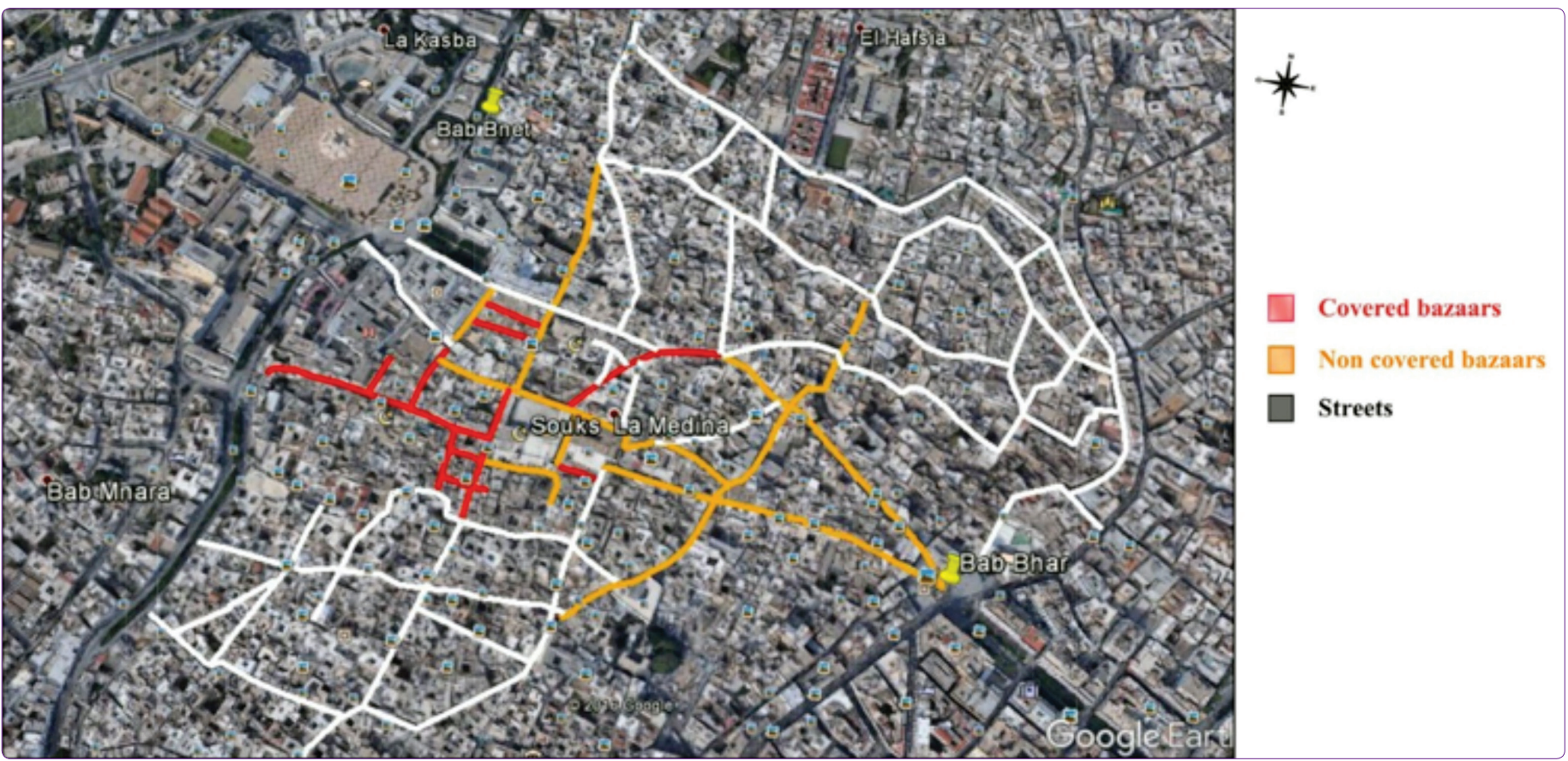

Figure 6. Spatial configuration of the central Medina (Provided by authors after Google earth). 


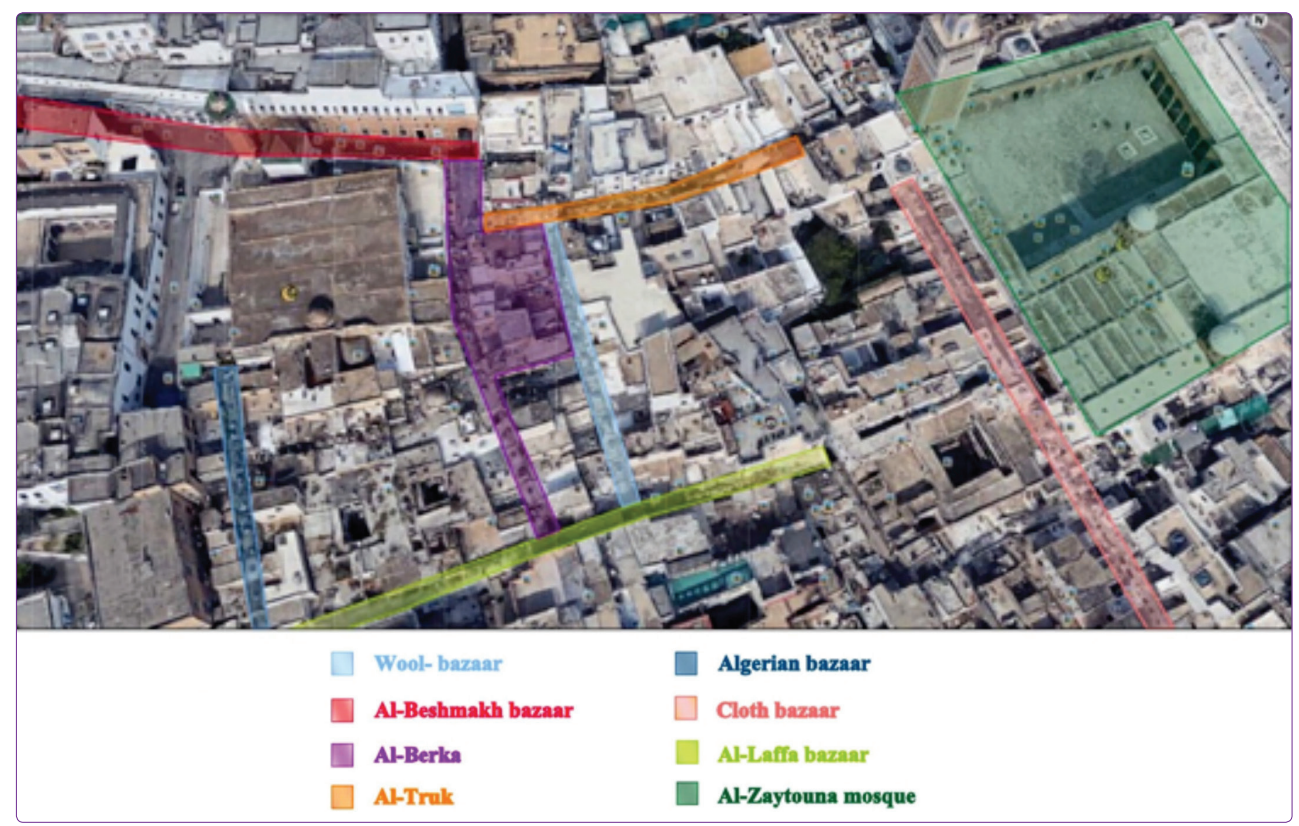

Figure 7. Functional organization of the chosen area (Provided by authors after Google earth).

bulrush. As mentioned by Ahmed Saadaoui, by 1670 under Shabân Khûja Dey, the cover was replaced by a wooden frame. This frame had been recently replaced by vaults. However, those vaults as it can be noticed in the Figure 6, had not totally kept the old traditional aspect since electricity and air cooling cables are placed with a hazardous way. Although it can be noticed in the Figure 6 that some traditional aspects could be conserved like the doors' sidings of the shops, some new traits are figured out. In fact, some old shops or depository spaces were transformed to bancs' branch or to new touristic shops (Figure 8).

All the shops were preceded by built benches supported with columns from identical structure and joined to Yüsuf Dey's mosque. However, it was noticed that those bunches were blocking the circulation fluidity in the bazaar, thus under Hammuda Pacha by 1800 , they had been totally removed. In the beginning of the $16^{\text {th }}$ century, this souk was considered as the most beautiful and most organized. It is noticed that this part of the Medina's bazaars has components subjected to the public use like the two fountains. In fact, one of them was placed in the beginning of the bazaar, externally connected to the minaret of 'Al-Zaytouna' and the second was in the end of the bazaar connected to an aqueduct.

As said by Saadaoui, 'Yüsuf Dey's minister 'Âli Thâbit' established in the same artery of the Medina, a 'maydât', a public latrine and ablution place and beside it he opened a cafe which was subjected to 'Habous'". This cafe still ex-

\footnotetext{
As explained by Khalfoune Tahar, The "Hbous" is a As a "part and parcel of the Islamic Shariah, Habous is the legal act through which personal property or realty, either from individuals or from the State, is bequeathed to a charitable or public interest organization.
}

ists in the same bazaar with a renovated aspect. What is special in this space is the existence of one saint's grave in the middle (Figure 9).

\section{'Al-Berka' Souk}

The second bazaar of Beylik Area is situated in the heart of the Medina and established after 1610, under Yüsuf Dey. In that time it was a black slaves' bazaar where plugs can also be found. The bazaar still exists but in its transformed function. In fact, by 1846, a decree about the slavery abolition had been announced by Ahmed Bey the first. After that time, 'Al-Berka' had been converted to a jewelry market and an auction place. It remained in its old state till nowadays; only its eastern entrance opening to the 'Kasbah' had been renovated by 'ASM' after 2000 (Figure 10).

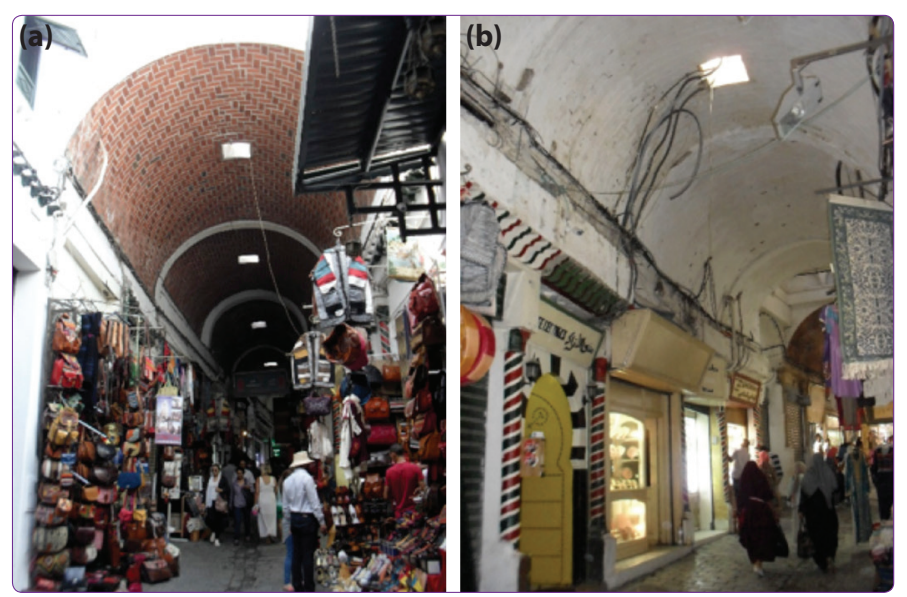

Figure 8. (a) Entrance of "Al-Truk" bazaar, (b) Electricity and air cooling cables in the bazaar's roofs (Provided by $1^{\text {st }}$ author taken on $20^{\text {th }}$ of July 2016). 

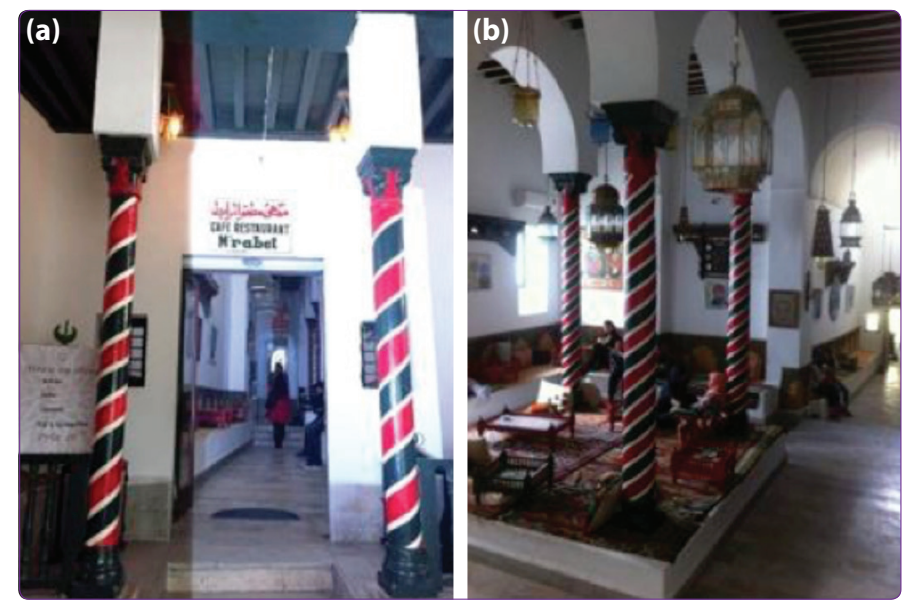

Figure 9. (a) Entrance of Al-Mourabit cafe restaurant. (b) The cafe from inside (URL: Www.tripadvisor.com seen on $16^{\text {th }}$ of August 2016).

This souk is a crossroads of four streets. Their intersection forms a small area divided by three pathways marked by two rows of columns. Those columns are supporting the vaults covering the space (Figure 11).

As was described by Ahmed Saadaoui, "the bazaar of such commerce is always ornamented with human products since unsatisfied owners of niggers decide to resell them easily". This had animated the souk's movement; it was an active bazaar where commerce was properly working. Although it was on a time when $10 \%$ from the Medina's population were Jewish and Christians, they were not allowed to own slaves. This kind of commerce concerned Muslims only. Selling slaves used to be according to auctions and with an emulating manner; every chosen slave had to be showed to all the bazaar taken by hand and walking in all the area.

By 1846, Tunisia lived the slavery abolition under Ahmed the first. Thus, the bazaar was transformed to a precious metals' trading place. However, it kept its spatial configuration. Even marks of ropes with which they used to tie up slaves still exist in the columns. Showing a meaningful graved memory, they had been kept like they were in old times (Figure 12).

As it can be noticed, the old existing benches were removed to make the circulation easier but the whole structure remained the same. Even the four gates are kept and they still been used till nowadays. Since the products sold are precious, at nights the gates close. And like the other covered bazaars, it has a problem of electricity cables coming from all sides with a hazardous way. In this area, even pavement has been changed since it is one of the oldest existing covered bazaars of the Medina. However, the culture of enclosure and privacy of goldsmiths' trading is still existing.

The memory of the slave market Al-Berka, is a memory of an anchor point in Tunisians' history; the slavery's abolition. No conflict existed between presently shopkeepers, current users of the city and slaves. But keeping slavery traits in the bazaar's space is a kind of continuous celebration of a community's freedom. It can be opined that those kept traces witness a compassion with the slaves' lived memory. The Medina of Tunis bazaars embrace two different remembering stimuli; the first are remembered experiences which disappeared and had been shared through people's testimony. The second remembering stimuli is existing in architectural traces of Al-Berka (the slave market previously). It is true that two remembering shapes are stimulating different collective thoughts; one is fostering a nostalgia feeling, the other is nourishing compassion and celebration of a turning point in the Tunisians' history but combined they are both witnessing the resistance of collective remembering act.

\section{The Medina of Tunis Between Cultural Memory and Globalization's Trends}

The normal processes of change in todays' modern soci-
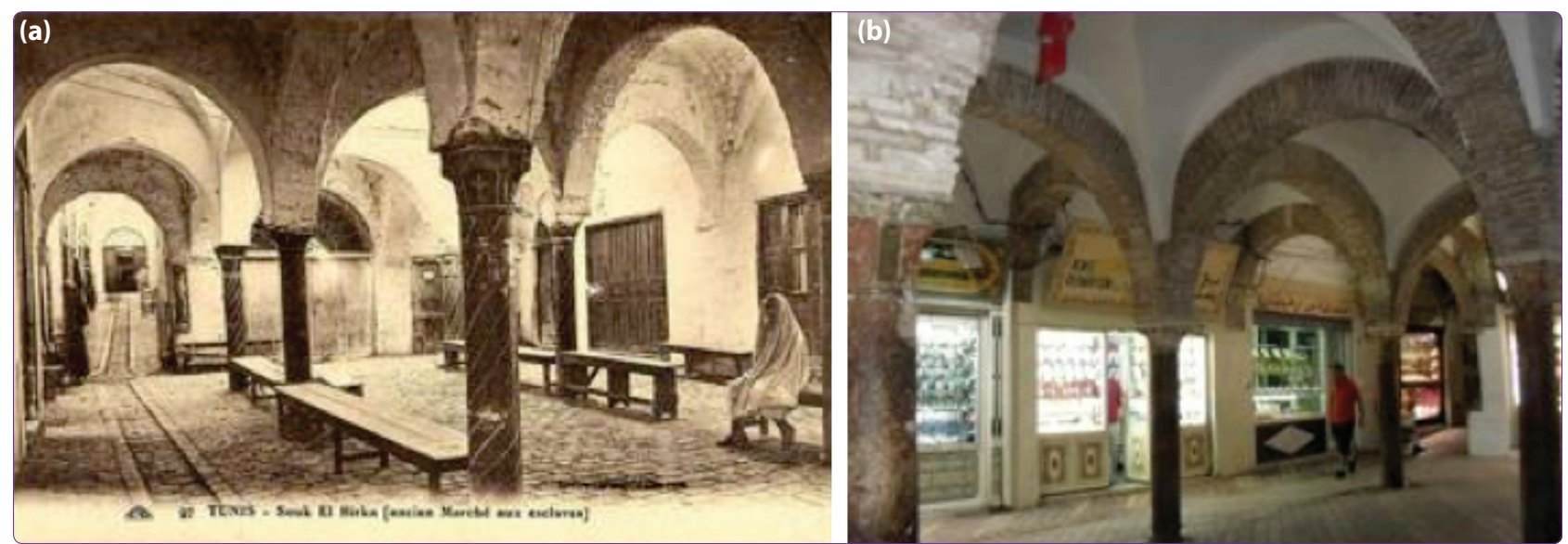

Figure 10. (a) "Al-Berka" bazaar in the end of the $19^{\text {th }}$ century, (b) "Al-Berka" bazaar presently ([a] http://www.delcampe.net/, [b] provided by $1^{\text {st }}$ author $16^{\text {th }}$ of July 2016). 


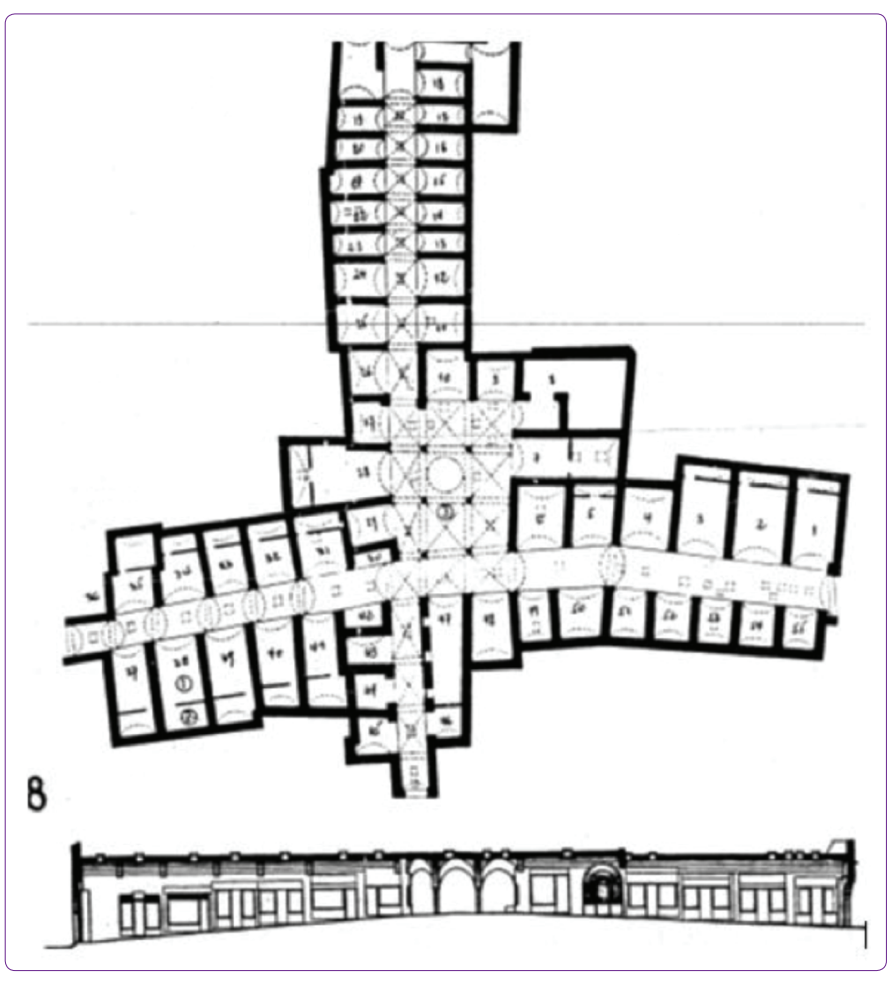

Figure 11. Plan and section of "Al-Berka" bazaar established in 1987 (Provided by ASM [Association of safeguarding of the Medina]).
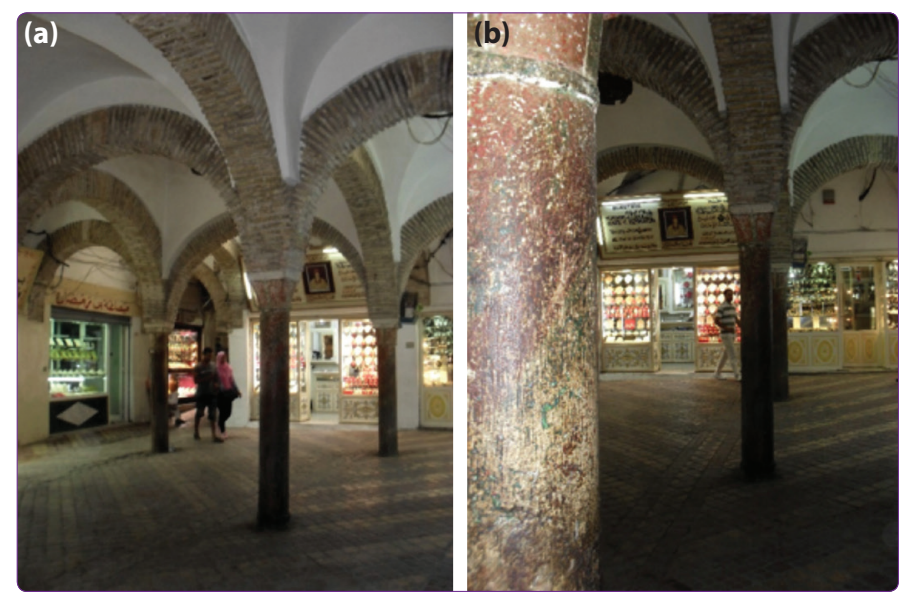

Figure 12. (a) Central area of the covered bazaar, (b) Ropes' marks in columns (Provided by $1^{\text {st }}$ author on $20^{\text {th }}$ of July 2016).

eties endanger a community's ritual practices and skills as well as built cultural forms. However, this seems countered in the Medina of Tunis' different hub of bazaars. The Medina's bazaars could preserves traditional patterns of individual ownership and an unusual longevity of shops and streets. Today, the medina of Tunis is an architectural symbol that has a considerable significance for the Tunisian national identity. It has an influential role in the shaping and understanding of life-world reality for the Tunisians' history. According to Anton Escher and Marianne Schepers, this contribution of Medina towards Tunisian history and memory was a significant but a very gradual process.
Through what had been analyzed in the previous part, it can be deduced that the Medina's bazaars are still a tangible witness of identity resistance. And as by the Egyptian workshop engineer Ibrahim Mostafa Eldemery, "place identity implicit psychological structure; it is also considered a cognitive structure that contributes to global selfcategorization and social-identity processes." It means, identity emerges from involvement between people and place. In other words, identity is a collective property of a given community; a property which is seen by John Tomlinson as threated by globalization:

Identity, then, like language, was not just a description of cultural belonging; it was a sort of collective treasure of local communities. [...] Into this world of manifold, discrete, but to various degrees vulnerable, cultural identities there suddenly burst (apparently around the middle of the 1980s) the corrosive power of globalization. (John Tomlinson 2003. p.1).

What question here is how globalization had affected various strategies of planning and developing in the Tunisian Medina? Globalized cities' seeking to form an international culture, are supposed to 're-invent' themselves. This implies that in areas requiring urban renewal, there is a neglect of existing traditions or at worst a contribution to their collective amnesia. In the Medina of Tunis, products as well as spatial configuration are running a risk of mutation which could affect the bazaars' identity. However, bazaars still reflect upon a resistive trait against globalization. This fact is resulting from the medina's being a site of memory or like Pierre Nora calls it, a significant 'lieux de mémoire'. It is a site of social remembering, as Asrid Erll qualifies it, a site of 'intergenerational memory' reflective of a society's heritage.

According to Astrid Erll, social remembering within collective memory is an 'identity formation', thus the social remembering resulting from lived experiences in the bazaars can witness about the Median's engraved identity.

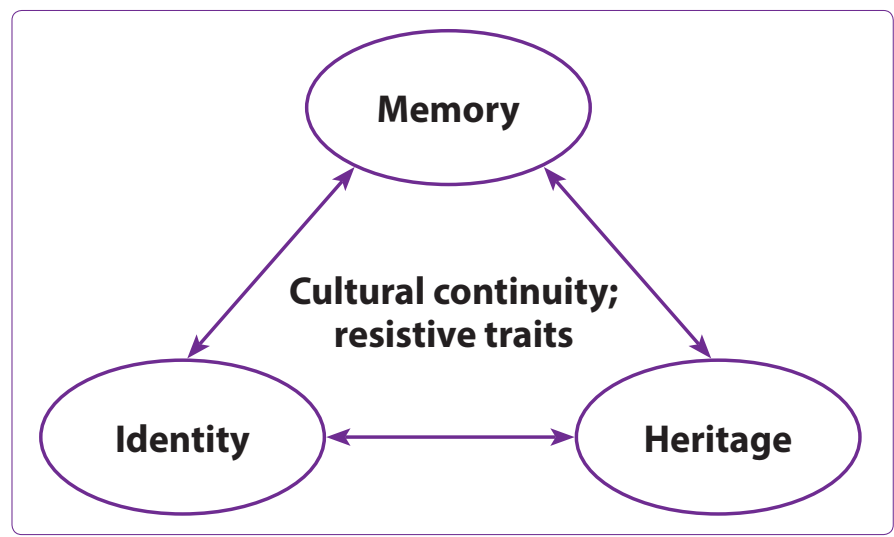

Figure 13. Heritage, identity, collective memory: Cultural continuity's resistance tripartite relation. 
Besides its being a residual space, the Medina is also a "particular space": it is one cradle of Islam's Arabic trait. In fact, Jallel Abdelkafi described it as "the historical space" of Tunisian agglomeration. Thereby, the medina's history is a mirror of collective memory; it is there where the Ottoman Empire started to build a new urbanity following a mixture between Hafsid architectural principles and Ottoman ones. It is also there where the influential French colonization started and finished.

\section{Concluding Comments}

According to MEDNETA ${ }^{3}$ project overviews, the Medina's bazaars are running a risk of artisans' migration to other jobs due to the degradation of products' quality and business profitability. This happened due to competing Asian low cost products and the random availability of raw materials. This is without forgetting the shift of some craftsman from shops to old Fonduks and to some residential buildings. Despite those facts, several bazaars like 'AlBerka' or 'Al-Truk' still reflect upon a collective treasure of local Tunisian community; an engraved collective memory forming the bazaars' identity.

What can be concluded from the present site reading is that although the Medina's main bazaars changed with a relative way, they are still reflecting social lived experiences like slavery and its abolition, the cafes and their role in socialization, the Zaytouna mosque and its being the most prominent religious center in the whole Medina. In fact, although the spatial configuration of several arteries has changed in the central Medina, it is still showing a potential power of place; it is a living landscape with common sense of place.

This resistive trait of the Medina's bazaars can be translated within the tripartite relation heritage, identity, collective memory or social remembering. As it's described in the (Figure 12), social remembering of architectural heritage is itself a shaping of architectural identity. It is also what had been advocated by Talja Blokland who considers that collective remembering through place making is interconnected to social identity shaping. Thus, despite the changes that globalization is enforcing in public gathering spaces, Tunis' bazaars are still keeping their identity and cultural continuity (Figure 13).

The Bazaars in the Medina of Tunis can be a tangible witness of globalization flows of 'market capitalization' and historical sites' urban homogenization's threats. It became unknown whether globalization can be considered as a risk or a sustainability reinforcement for traditional bazaars; from one hand capitalizing markets is a good point for economy, from another hand, homogenizing

\footnotetext{
MEDNETA is a project enhancing cross-border cultural dialogue and cooperation among multiple stakeholders and it aims to support creativity in the Art, Crafts and Design and concerning some communities inhabiting the historical cities in the Mediterranean Basin. [9, p 59].
}

products is a threat for crafts' continuity and thus for their architectural spaces' resistance. Thus, the traditional role of architecture as "bearer" of cultural meaning brings with it challenges in the modern world.

\section{References}

Abdelkafi, J, (1989). La Medina de Tunis Espace historique, CNRS press.

Ardalan, N, (1980). "Places of public gathering", proceedings of seminar five in the series, Architectural transformation in the Islamic world, Jordan.

Augé, M, (2010). «Retour sur les " non-lieux ». In: Communications, 87, pp. 171-178, URL: http://www.persee.fr/doc/ comm_0588-8018_2010_num_87_1_2631, put online on 03/06/2016, p 2, [accessed 02 September 2016].

Blokland, T, (2001). "Bricks, Mortar, Memories: Neighborhoods and networks in collective acts of remembering", International Journal of Urban and Regional Research, Volume 22.2 June 2001.

Eldemery Mostafa, I, (2009). "Globalization challenges in architecture", Journal of Architectural and Planning Research, Vol. 26, No. 4,Theme Issue: Work Beyond Boundaries (Winter, 2009), pp. 343-354, Locke Science Publishing Company, Inc, URL: http://www.jstor.org/stable/43030883, [accessed: 27 October 2016], p. 5.

Erll, A, (2011). Memory in culture, Palgrave Macmillon, US, p, 18. Escher, A. and Schepers, M., (2007). Revitalizing the Medina of Tunis as a national symbol, (CRISSMA) Centro di Ricerche sul Sistema Sud e il Mediterraneo Allargato, working paper $\mathrm{N}^{\circ} 12$.

Jan, A, (2008). "Communicative and cultural memory", (Ansgar Nünning (Hg.), Cultural Memory Studies. An International and Interdisciplinary Handbook, Berlin, New York, 109-118.

Khalfoune, T, (2005). " Le Habous, le domaine public et le trust ». In: Revue internationale de droit comparé. Vol. 57 NN2, 441-470. URL: <http://www.persee.fr/doc/ridc_00353337_2005_num_57_2_19355>, [accessed on 05 Juin 2016].

Koca K. S. (2010). “Tunus'un Medinaları'nda Mekansal bir deneyim: Dokular, Renkler, İzler", Mimarlık Tasarım Kültür Sanat, Ocak 2010.

Mouhli, Z. Bejaoui, F. and Gazzah, A. Tunis patrimoine vivant conservation et créativité, ASM (association of safegarding of the Medina) 1980-2012.

Mouhli, Z., (2014). Industries créatives et régénération urbaine dans la Médina de Tunis, MEDNETA project, (ASM) Association for Safeguarding of the Medina of Tunis.

Nooraddin, H, (2012). "Architectural Identity in an Era of Change", Developing Country Studies Journal, Vol.2, Nº10, p. 2.

Pellegrin, A, (1952). Le vieux Tunis, les noms de rues de la ville arabe, Espace Diwan, 38-47.

Saadaoui, A, (2010). Tunis ville Ottomane trois siècles d'urbanisme et d'architecture, Centre de publication universitaire, Tunis, p. 67.

Santelli, S., (1995). La ville le creuset méditerranéen Tunis, DemiCercle Edition, CNRS.

Santelli, S., (1995). La ville le creuset méditerranéen Tunis, DemiCercle Edition, CNRS.

Santelli, S., Medinas Traditional architecture of Tunisia, Dar Ashraf Editions, Tunis. 
Temple, N, "Cultivating architecture", (2012). Emmons, P, Hendrix, J and Lomholt, J, The cultural Role of Architecture contemporary and historical perspectives, Routledge Taylor and Francis Group, London and New York.
Tomlinson, J, (2003). "Globalization and cultural identity", p. 3. Tomlinson, J, (2003). "Globalization and cultural identity", URL: <https://www.polity.co.uk/global/pdf/GTReader2eTomlinson.pdf>, [accessed on 2nd of November 2016], p. 1. 